\title{
Some Thoughts on the PROBLEM of IDENTIFICATION OF DEMES: The ANCIENT BOZBURUN PENINSULA
}

\author{
DEME'LERIN KİMLÍK SORUNSALI ÜZERINE BAZI DÜŞÜNCELER: ANTIKK
}

\author{
BOZBURUN YARIMADASI
}

\section{E. DENIZ OĞUZ-KIRCA*}

\begin{abstract}
The Bozburun Peninsula, lying in southwest Anatolia, facing the island of Rhodes, was originally acknowledged as being a part of Carian territory. It was only during the III $^{\text {rd }}$-II ${ }^{\text {nd }}$ centuries B.C. that the Classical Peninsula which was equivalent to a polis and conurbated through a koinon of komai, was transformed into a periphery, reorganized under the protectorate of Rhodes and became an incorporated-Hellenized part of the island until the Roman takeover.

Although it may seem that the newly introduced constituents of the Hellenistic mainland, the demes, were the equivalents of ktoina reflecting egalitarianism and having their form within the island's administrative pattern, they were possibly the later forms of the ancient territorial model formed by a long-settled and decentralized network of Carian komai. Problems with the identification of demes and the nuclei thereof have caused long standing debates amongst scholars. This paper aims at reassessing the problem of identity in view of the natural and social territoriums, in respect to the available knowledge to date and the results of recent surveys carried out between 2009 and 2012 which encompassed the area beginning from the horizontal line between modern Deliktaş Bay and Bayır Village in the north and stretching down to the isthmus in the south.
\end{abstract}

Keywords: Bozburun Peninsula • Carian Chersonesos - Peraea • demes - Identification • Territorium
Öz: Güneybatı Anadolu'da, Rhodos'un hemen karşı yakasında yer alan Bozburun Yarımadası, esasen Karya topraklarının bir parçası olmasıyla özdeşleşmiş idi. Klasik Dönem'de, fiziksel büyüklüğü ve kendisini tamamlayan en az 7 (yedi) kome’nin oluşturduğu federatif yapısıla bir polise denk sayılan Yarımada, M.Ö. III.-II. yüzyllar boyunca ve Rhodos'un hamiliğinde yeniden örgütlenmek suretiyle tamamen bir periferiye dönüştürülmüş ve Romalıların egemenliğine girene kadarki uzun Helenleşme sürecinde adanın ayrılmaz bir parçası haline gelmiştir.

Hellenistik anakaranın yeni tanıtılan unsurları olarak deme’ler, her ne kadar temelleri adanın yönetsel şablonlarında var olan ve eşitlikçi anlayışı yansıtan ktoina'lara karşılık geliyor gibi görünse de, bu yerleşimler olasılıkla uzun zamandır bölgede yerleşik ve merkeziyetçi anlayıştan uzak Karya'lı kome şebekelerince oluşturulmuş antik teritoryal modelin daha geç formları idi. Bölgeye ilgi duyan gezginler ve bilimadamları, deme ve merkezlerinin tanımlanması konusunda uzun süre meşgul olmuştur. Bu makalede, Hellenistik dönemden itibaren yükselişe geçen deme’lere ilişkin kimlik sorunu, fiziksel ve sosyal sınırlar gözetilmeye çalışılarak ve; bugüne kadar üretilen bilgiler ve kuzeyde modern Deliktaş Koyu-Bayır Köyü arasındaki sınır hattından başlayıp daha güneydeki kıstağa kadarki alanda (T.C. Kültür ve Turizm Bakanlığı’nca verilen izin kapsamında) yürütülen 2009-2012 sezon çalışmalarından elde edilen sonuçlar ışı̆̆ğında yeniden irdelenmektedir.

Anahtar Kelimeler: Bozburun Yarımadası - Karya Khersonesos'u • Pera • deme'ler • Tanımlama • Teritoryum

* Dr. (Independent Researcher), Middle East Technical University, Dep. of Settlement Archaeology, Ankara. zedok33@gmail.com 


\section{Introduction}

The Bozburun Peninsula is situated on the south-western coast of Anatolia, within the modern borders of Turkey (Map 1). The natural boundaries within which we mainly investigate concerning the demes in this paper, begin from Hisarönü near Datça (ancient Cnidus)-Bozburun crossroad, extend towards the middle and end near Bozuk Village in the very south, facing the northern sector of the island of Rhodes. Originally being Carian, the mainland was acknowledged as the Carian Chersonesos during the Classical era. It was possibly following the synoecism of Rhodes in 408 B.C. that the Rhodian State began gradually to take a formal interest in the mainland. The entire area was fully incorporated around 166 B.C. albeit there was the clash of interests and continuous struggles between the Diadochi until the early II ${ }^{\text {nd }}$ century B.C. ${ }^{1}$. The interest of Rhodes opened the way to the enjoyment of power in Carian territories that the island must have turned into an advantage by the beginning of the III ${ }^{\text {rd }}$ century B.C. If a successful diplomacy ${ }^{2}$ of Rhodes had never been there, the Peninsula as part of the newly introduced "Rhodian Peraea" would not perhaps have fallen into the periphery and been controlled for a longer period than expected. I shall not debate here some different conceptualizations about the Rhodian Peraea regarding the two separate status- namely the Incorporated and Subject Peraea in which matter Fraser \& Bean, Jones and van Bremen have contributed a great deal to the discussions ${ }^{3}$. We take it for granted that the readers are familiar with both, and that the questioned area is covered by the Incorporated Peraea which stretches to Physcus and Cedrae further north.

The Carian territories were quite familiar with Archaic type hilltop settlements and komai in the plain areas $^{4}$. But, anyone who takes a flash back to the history of settlement may see that the organization of the Carians predates the Iron Age, however, these were predominantly concentrated in the northern sector, around the Meander with a handful of sites (e.g. Aphrodisias). Although the settlement patterns in the Early Iron Age do not present a compact picture, the period down to the $\mathrm{VI}^{\text {th }}$ century B.C. is, to an extent, informed with some degree of identity expressed in a limited image of koina life ${ }^{5}$ and of partly settled komai forms (thereafter) which, however, began to decline by the beginning of the IV $^{\text {th }}$ century B.C., due to the destructive results of the Peloponnesian Wars and ratification of the King's Peace in 378 B.C. The subsequent peaceful atmosphere showed its effects in a change in the settlement patterns ${ }^{6}$. Rural life was

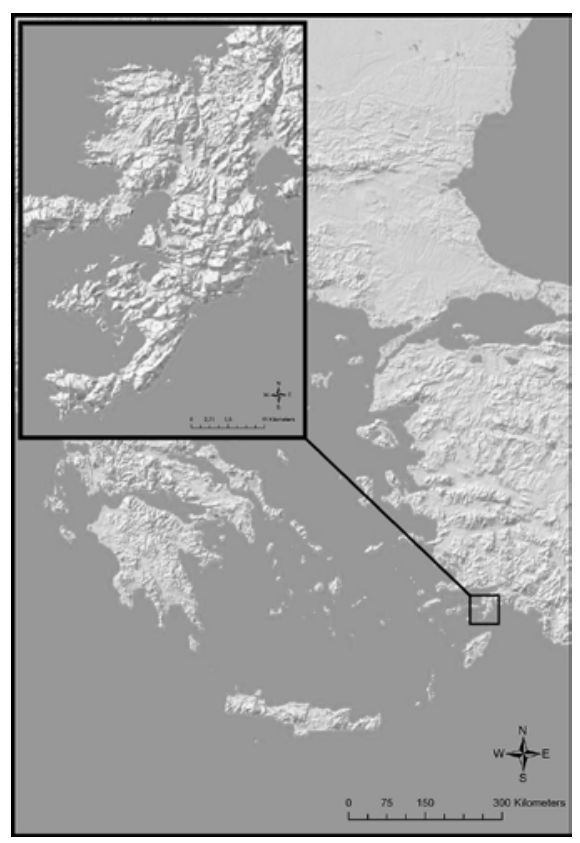

Map 1. Location of the Bozburun Peninsula

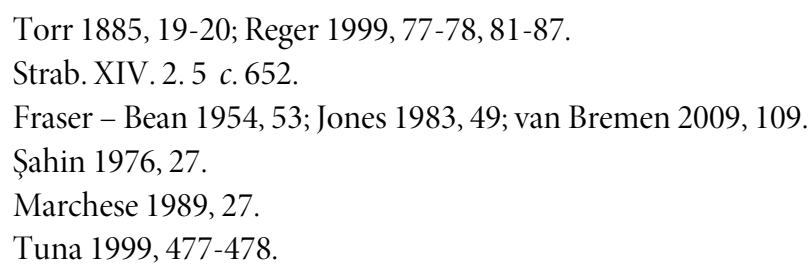


gradually altered by the time the famous satrap Mausolus invited mountain people to the newly designed cities to become merged with Greek cultural and political life ${ }^{7}$. He put synoecism in effect by incorporating the Lelegian komai into the domain of Halicarnassus; it was probably him who let the other koina co-exist and compiled all of them for the creation and development of the poleis. He transformed inland Caria into a territory where komai and poleis co-existed, forming a half-polis pattern. Some early inscriptions (e.g. Hyllarima) disclose hints such that co-habitation also applied to the coastline ${ }^{8}$. As Caria developed in the Hellenistic era (following the decline of Mausolus' and his successors' power), we may speak of reorganization in the sense of dioikismos, such that the remote memory of the Carians were rekindled via community reflexes inherited from the Early Classical period. In other words, the demes, as the newly introduced practices of Rhodes on the mainland as early as the Hellenistic period, might have recalled the historical experiences attributable to past ways of living in the form of komai.

What about the toponomical expressions in Caria, hence the peninsula? Unsurprisingly, the geographical boundaries of Caria can be imperceptible due to the survival of multiple races across the Meander line. We may well opt to bank on the views focusing on ethnic identity, rather than the physical limits ${ }^{9}$ as may be valid for the case of the Classical Peninsula. Chersonesii, just as referred to in the Athenian Tribute Lists (ATL), was the adjoining part of the Cnidian Chersonesos ${ }^{10}$. Although there remain unknown sites paying tribute in Caria, the Carian Chersonesos was mentioned as Xeppovíoto (Cherronesioi) being almost at the end of the list ${ }^{11}$. The ethnicon was Chersonesioi ${ }^{12} /$ Chersonesios (Xeppovíoเos) while the toponym was recorded as Chersonesos

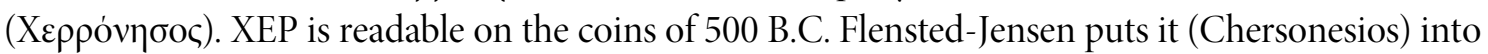
the status of a polis. The reason seems that it appeared in ATL from 452/1 to 429/8 B.C. It is registered twelve times, twice completely restored, and paid a phoros of 3 talents until 447/6 B.C. From 444/3 to 441/0 B.C., the payment decreased to about 2 talents. It repaid a tribute of 3 talents in 433/2 B.C. ${ }^{13}$. With additions and corrections, the nearest approximations made by Meritt et al. show that 2 talents (4200 drachmae) were paid by the Carian Chersonesos in the $\mathrm{V}^{\text {th }}$ century B.C. The situation is, however, a little contradictory since it was an original member of the Delian League in 478/7 B.C., was reassessed in 450 B.C., and stood in the quota list of 454/3 B.C. and was defined as "part of the city of Cnidus" ${ }^{14}$. Taking the whole Peninsula as a polis, the status may be owed to the internal organization of the Chersonesos Koinon ${ }^{15}$ made up of the Carian komai.

Difficulty in fixing names for a number of settlements arises from the Carian language which still has not been completely deciphered; however, the origins of some settlements have been questioned at the same time. Uyguç underscores that names containing SS, ND and ASA (e.g. Bybassos,

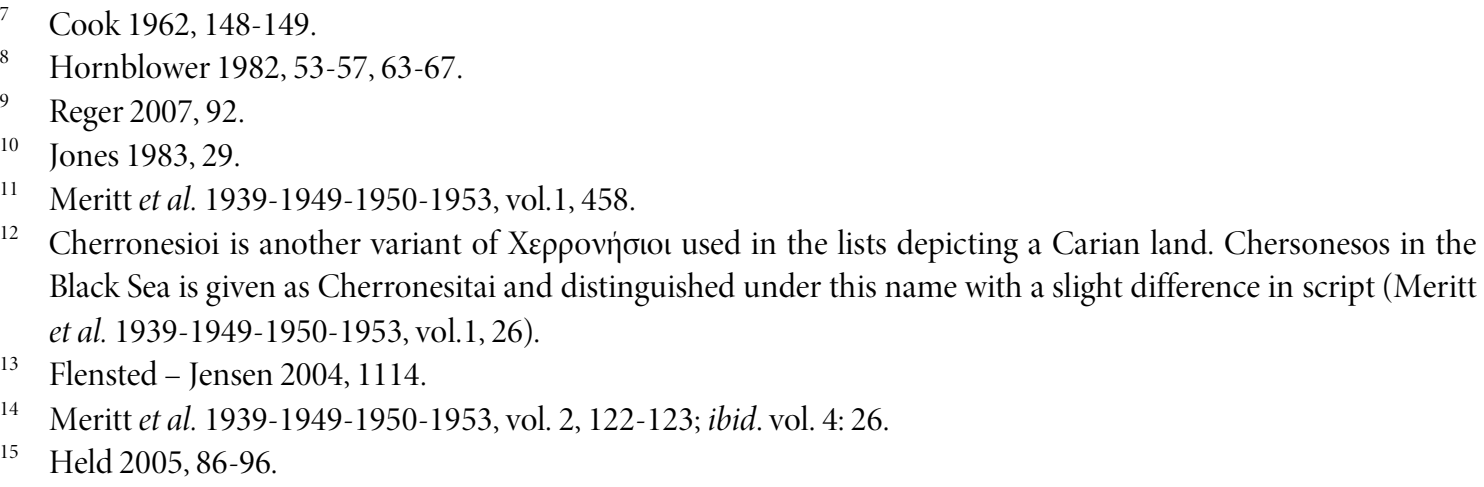


Halicarnassus, Thyssanous, Kolossia) find etymological expression in Anatolian languages ${ }^{16}$. We also have reasons to judge whether a site could be of Carian origin by looking at onomastics as a strong adoption of ethnic identity - if locals made up the vast majority. Reger draws attention to the use of dual names in Greek and Carian during the Hellenistic period and that co-usage could even continue into Roman times. Notable examples come from cities like Mylasa and Stratonicea where local Carian names such as Thyssos, Silbou or Koldoba have been recorded ${ }^{17}$.

\section{The Peraea- Successor of the Chersonesos}

Following her synoecism with the three old poleis, Ialysos, Kamiros and Lindos ${ }^{18}$, the new federal country of the Rhodian State designated herself with numerous demes which were allocated to either polis ${ }^{19}$. Under a stable constitution and the efficient state organisation of the island, these poleis together with their demes were treated equally on political grounds ${ }^{20}$. Over time, the Peraea and the islands became subject during elections to the procedures of the federal law, as attested in the early III ${ }^{\text {rd }}$ century B.C. Kamiran decrees ${ }^{21}$. The situation continued even after the declaration of Delos as a free port but the entire Peninsula was lost with advent of Pompey in 67 B.C. ${ }^{22}$. Inscriptions also illuminate the Rhodian way of ruling; for instance, along with information about the Carian troops under the command of Rhodian generals, some Carian cities, by decision of another Carian league - the Chrysaoric Koinon, are known to have made alliances with the island during the Second Macedonian War (200-197 B.C.). Hence, this period of warfare was also a critical turn for the full recognition of the Rhodian mainland. It seems that the Carian Chersonesos may now be extended a few generations earlier, as also of Rhodian descendants, which was perhaps officially acknowledged by the end of the III $^{\text {rd }}$ century B.C. ${ }^{23}$. Although the former administrative and political framework of Caria is rather reflected through a network of koina which developed into the Hecatomnid era, the territorial system of the Peraean demes, based on the notion of ktoina, also had roots in the governing model of the three old mother poleis before the synoecism process on the island of Rhodes ${ }^{24}$. Early organic relations, thus possible amicable relations before the Social War (357/6 B.C.) might provide an alternative answer. It is also likely that the Peraeans were not alien to the notion of synoecism or it could not have been very unusual, since that of Mausolus and Rhodians could be treated at least within a similar context ${ }^{25}$ - cultural and political unification (excluding the conditions rooted in the genesis), vis-à-vis the practices of some others, e.g. Megalopolis, which experienced it in physical terms. Mention by Polybius about the "already there" landholdings of Rhodian citizens in Caria and Lycia after 164 B.C. ${ }^{26}$ might further aid the chronological puzzle to some extent.

16 Uyguç 1992, 57.

17 Reger 2007, 91.

18 All are assumed to be Dorian Greek poleis.

19 Hornblower - Spawforth 2003, 1316.

20 Papachristodoulou 1999, 29-30.

21 Gabrielsen 2000, 193-195.

22 Torr 1885, 27-28, 66 .

23 Aydaș 2010, 31-39.

24 Hornblower 1982; Ma 1998; Şahin 1976; Held 2005; Berthold 1984; Fraser - Bean 1954; Gabrielsen 2000.

25 Hornblower 1982, 84.

26 Polyb. VI. 31. 4; Hornblower 1982, 83-84. 


\section{The Problem of Generic Identification}

Inspired by the standard image of an Archaic city, demes of the Classical period were typical rural elements of the countryside ${ }^{27}$. Demes can be traced as far back as Solon and Cleisthenes, at the close of the $\mathrm{VI}^{\text {th }}$ century B.C. ${ }^{28}$. The last sub-tribal division of the demos was the deme, no further ${ }^{29}$. In explaining the term deme, Hornblower \& Spawforth refer to "local territorial districts-villages, in effect - in Greece, and, by extension, the inhabitants or members thereof". Obviously, deme structures varied greatly according to size, from hamlets to larger towns ${ }^{30}$. Also defined as a geographical and political unit, a deme could have possessed more than one type settlement, each having its own necropolis ${ }^{31}$. If we turn back to the Peraea- a "peninsula settlement" in nomenclature, it was a network of rural sites and a conurbation of at least 9 (nine) demes which began to be explicitly recorded from the III ${ }^{\text {rd }}$ century B.C. These were most possibly Bybassos, Amos, Hydas, Syrna, Hygassos, Tymnos, Thysannous, Phoinix, Casarae. The thing is, as may be inferred from the compiled work of Bresson ${ }^{32}$ on the rich epigraphic inventory of the Peraea, a terminus post-quem for their commemoration (as retaining a Hellenized deme character) corresponds to the period 300-250 B.C.

On this subject matter, a constructive view was previously brought by Held who had limited the number of demes to 10 (ten) in the Chersonesos Koinon. Up to this point, nothing unusual concerning the spatio-temporal framework he had assigned to the demes of the Peninsula or anachronous to what is discussed herein below. The reason for my delimitation to somewhat more than two centuries (300-67 B.C.) is the full deme character that we can trace through the epigraphic database. A nuance unavoidably occurs when he uses the term deme in the earlier context, as being the komai of a sub-regional league/the heirs of now representable rural settlements, and formulates a list of the Chersonesos Koinon within which Loryma is included. He must be implying the continuation of the "demes" into the Hellenistic period; however the primary reason for stepping on a number like ten without tossing out Loryma (which was most possibly attached to the Hellenistic deme of Casarae) appears to be that his criterion is based on the fortified settlements of the Peninsula $^{33}$.

A crux is that different sources recall different Peraean names, hence demes which in the end raise problems in their assignment to the three old poleis. The views of Papachristodoulou and Jones seem to be the most explanatory on this subject matter. Accordingly, there is evidence on the number of Rhodian demes listing 55 certain names and 12 possible or uncertain names. Out of these, 33 were located on the island of Rhodes, 13 in the Incorporated Peraea, seven on the islands while the rest remain unidentified. It is quite certain that Lindos had 12 demes. We are not, however, able to decide whether this number could be raised if part of the missing demes is reconsidered in

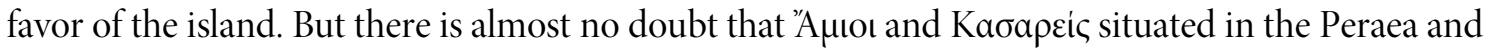
Bрvкоúvtıo were attached to her. From out of the 19 demes of Kamiros, five belonged to the

\footnotetext{
27 Crielaard 2009, 351-353.

28 Hornblower 1991, 156-158.

29 Osborne 1990, 269-271.

30 Hornblower - Spawforth 2003, 446-447.

31 Papachristodoulou 1999, 31.

32 Bresson 1991.

33 Held 2005, 86.
} 
Kamiran territory in Rhodes, six demes, with certainty, to the Incorporated Peraea and one in Chalke. The remaining seven demes were probably located on Rhodes. Casarae was previously attached to Lindos but in late periods becomes obscured precluding any thorough assignment. The situation is very debatable for Ialysos where the new asty was founded within the city of Rhodes during synoecism. It was determined that nine demes were located on the island while two remained on the mainland. No deme has been evidenced for the dependent islands. Of these two, Cryassus has been identified in favour of the Rhodian Peraea with certainty but has not been satisfactorily located. Tracing inscriptions, the location of Patyreis has been reported for the same region, as well. In any case, the location of the demes of Ialysos in the Peraea is problematic. In spite of various tenets, Papachristodoulou suggests that Ialysos had a total number of 12 demes and that the 12-deme model applicable to the island might be a start, based upon equal representation ${ }^{34}$. Accordingly, should egalitarianism be the criterion for the three old poleis in all respects, each could have possessed the same number of demes in the Peraea, as well. Nothing new has supported this hypothesis. Notwithstanding, let's posit for a while that all had the same number of demes (taking into account the number of at least 13 demes except for the unknown or fixed), there must have been at least six demes allocated to each polis due to the certitude regarding Kamiros.

Limited to the Peninsula (considered with some other associated demes, having a close proximity or still lacking identification), the issue of the generic identification of demes or any other relevant (e.g. demos) may be tackled through tracing them from the north to the south. A deme of Lindos in the $\mathrm{IV}^{\text {th }}$ century B.C., Physcus formed the core of the Rhodian Peraea, as the largest deme with a spectacular harbour. The Acropolis is associated with the remains of Hellenistic and earlier walls in the northern part of where modern Marmaris now lies ${ }^{35}$. A purely Carian demos and possibly retaining the most civic tradition on the mainland ${ }^{36}$, Cedrae was an important base where the first settlements have been dated to the $\mathrm{V}^{\text {th }}$ century B.C. Known through the inscriptions, Hellenisation in Cedrae with sanctuaries, a theatre and agora originally built in the Rhodian fashion, was completed by the III ${ }^{\text {rd }}$ century B.C. It was then subjugated by the Rhodians in the II $^{\text {nd }}$ century B.C. following the unrest between Rome and the Seleucids ${ }^{37}$. There lay Bybassos and Amos to its south, and the others in the central and southernmost part of the Peraea. The status of Euthena (attributable to a peak called Altınsivrisi) is doubtful, although it occurred in the demotic lists of the Kamirans. Similarly, the deme of Amnistos, reported to be on a promontory near Karacasögüt Village between Physcus and Cedrae, was possibly attached to the same polis ${ }^{38}$. Marked as a polis by Stephanus Byzantinus, Amos (modern Turunç) was a Lindian deme (s.v. 'A $\mu$ oc) ${ }^{39}$ which was much later incorporated into the Rhodian domain. Fraser \& Bean and; Sherk ${ }^{40}$ restore two names, Cryassus (speculated to be around Taşyaka in the west of the Gulf of Fethiye) and Erine to Ialysos ${ }^{41}$

34 Papachristodoulou 1999, 32-40; Jones 1987, 243, 245, 249.

35 Fraser - Bean 1954, 57, 79.

36 Bean - Cook 1957, 68; Bean 1971, 154.

37 Diler 2007, 9, 32.

38 Fraser - Bean 1954, 80; Bean 2000, 163-164.

39 Rice 1999, 46.

40 Fraser - Bean 1954, 55-56, 80-81; Sherk 1990, 285.

41 The demos of Erine must have been spelled on purpose by Sherk, regardless of its former errant locations in lieu of Bybassos. 
while Meyer locates Erine to Lindos ${ }^{42}$. It was later corrected by Cook that Bybassos was the deme situated near Rena (Erine) Bay ${ }^{43}$ in modern Hisarönü. The status of Hygassos is uncertain, but is probably associated with either of the three poleis. Along with some others (e.g. Cedrae), it could have maintained a special situation by virtue of its late incorporation ${ }^{44}$. Regarding the deme of Hydas, there is one thing to consider in favor of the two poleis, as a tomb recorded in a cave below its Acropolis showed parallels with those detected in Kamiros and Ialysos of the $\mathrm{VI}^{\text {th }}$ century B.C. ${ }^{45}$. However, it remains uncertain until new evidence is presented.

Thysannous and Tymnos were Kamiran demes ${ }^{46}$. Mention of Kleinias, the son of Epigonus, as the eponymous official (hierothytas) in a religious decree (probably from the It century B.C.) found in Tymnos has caused scholars to associate this deme with its dependency on Rhodes. The Rhodian word ктoiva may validate this status ${ }^{47}$. Meyer and Fraser \& Bean assume that Phoinix was also attached to Kamiros, being the second largest deme after Physcus ${ }^{48}$. On writing about a Hellenistic epigramme from Lycia, Robert (1983) distinguishes between two similar ethnics in reading.

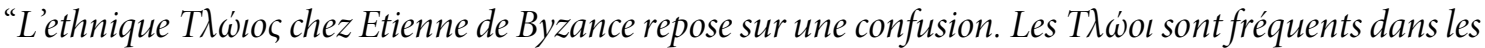
inscriptions de Rhodes et on les classait à la ville de Tlos. La question fut résolue par Hiller von Gaertringen: c'était une subdivision de Kamiros située dans la Pérée rhodienne et qui groupait les gens

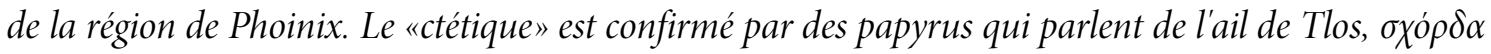

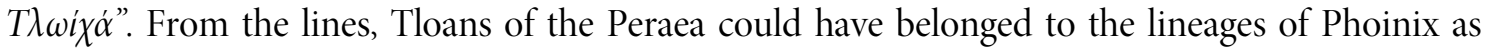
attached to Kamiros since Tloans appear in the list of damiourgoi, priests with demotics ${ }^{49}$. Also, inscriptions mentioning Athena and Zeus Polieus in the deme put it to the Kamiran side ${ }^{50}$.

Sherk assumes that Casarae was a Lindian $d e m e^{51}$. In one inscription, there appeared a name, Aristomachus who was the priest of Athena Lindia but adopted the son of Telestes who was of Casarae origin. Apparently, regarding Aristomachus of Casaraea origin ${ }^{52}$ would prove futile. A reality is that adoption was often practiced in Rhodes and the Peraea ${ }^{53}$. Although such instances are rather elusive, we have no way but to refer to a close interest from the polis of Lindos, and the inscriptions about the status of the neighboring site (of Loryma) noted shortly below. Syme (Sömbeki) and Elaeoussa (Kızılada) all fall within the borders of the Incorporated Peraea, as well ${ }^{54}$. It is Plutarch who informs us of the "Athenian fleet of 180 triremes" that landed on Elaeus in the Chersonesos $^{55}$. Except for Elaeoussa Island, Loryma and Physcus, almost none of the demes or sites

42 Meyer 1925, 51.

43 Bayrak 1961, 62.

44 Fraser - Bean 1954, 81; Papachristodoulou 1999, 38.

45 Benter 2001, 177-179.

46 Meyer 1925, 50-51; Jones 1987, 251; Dmitriev 1999, 250.

47 I.Peraia, no. 201; Bresson 1991, no.102 (I. 1); for the word ktoina see ibid. (I. 5). Also see Sherk 1990, 287. Hierothytas was probably the eponymous official before incorporation to Rhodes (ibid.).

48 Meyer, 1925, 50; Fraser - Bean 1954, 80.

49 Fraser - Bean, 1954: 80; Robert, 1983, 257; Bresson, 1991, 139.

50 Flensted-Jensen, 2004, 1110.

51 Sherk 1990, 285.

52 Fraser - Bean, 1954, 79

53 Rice 1988, 138-142; Rice 1999, 51-52.

54 Sevin 2001, 128.

55 Plut. Lys. IX. 4. 
in the Peraea are pronounced by Strabo. He conveys that, with a perimeter of eight stadia, Elaeoussa lies on the opposite side of modern Taşlıca, about 120 stadion from the island of Rhodes and four stadia away from the fortress of Phoinix (XIV. 2. 1-4, 14). From this viewpoint, Elaeoussa possibly had a relation with Phoinix as the island lying directly to her east. Syme ${ }^{56}$, not holding a deme status, was attached to the Peraea in the late Hellenistic period ${ }^{57}$. The island needs to be discussed according to the datable documents (one of the $\mathrm{I}^{\text {st }}$ century B.C.). It is a possibility that the Symaeans were attached to the administration of Casarae using the demotic Kaбapeve also because it has never been evidenced until now that the demotic $\Sigma$ vuaios was articulated by the Rhodian State ${ }^{58}$. Lindos inscriptions have revealed that Loryma was attached to Casarae ${ }^{59}$. Hence, we are only left with the assumption that the site was indirectly attached to a mother polis which was presumably Lindos, during the Hellenistic era.

In the views of Calder \& Bean, the demes of the western Peraea belonged to Kamiros, while those lying in the east were attached to Lindos ${ }^{60}$. If so, easy access to the bays and locations for harboring facilities could have been the fundamental reason for such designation. Considering the abovementioned and the availability of deme information, the possible relations are tabulated as follows:

\begin{tabular}{|l|l|l|}
\hline Ialysos & Lindos & Kamiros \\
\hline Hydas?** & Physcus & Euthena? \\
Cryassus? & Amos & Amnistos \\
Bybasssos? & Syrna? & Hydas? \\
Hygassos? & Casarae & Tymnos \\
& - Syme & Thysannous? \\
& - Loryma & Phoinix \\
& & Hygassos?**61 \\
\hline
\end{tabular}

Table 1. Possible Status of Demes and Mother Poleis

\section{Locations and Settlement}

Obviously, there appear to be problems with the Peraean toponyms and their possible extensions all over the Bozburun Peninsula. Divergent information conveyed by ancient writers is particularly weak or unsatisfactory. The ancient sites of the Bozburun Peninsula recorded in the 1973 Annals (Muğla Province) are incomplete and far from reliable, the relevant map inside depicts the modern center of Bozburun as Loryma. It is due to the authorities that Taşlica Village (Phoinix/Fenaket) is correctly located. Generally speaking, Bean's views have greatly encouraged scholars to take steps toward catching up with debates on the approximate coordinates of the Peraean demes.

In order to picture the Peninsula, we need to begin with divergent appellations and scripts whereby the first case is that of Kiepert who restores the Peraea to Sinus Doridus ${ }^{62}$. On one side,

\footnotetext{
56 Hansen - Nielsen 2004, 1314. Code Syme as a "collective external" under the city-ethnic.

57 Cook, 1961, 59.

58 Fraser - Bean, 1954, 86; Papachristodoulou, 1999, 38; Jones, 1987, 250-252.

59 Meyer, 1925, 51; Bean, 2000, 167.

60 Calder - Bean 1958.

61 The demes of Hydas and Hygassos may be dissociated, as having belonged to either deme, Ialysos or Kamiros.

62 Kiepert 1898, V. Gi.
} 
Mela's Peninsula rolls around three bays ${ }^{63}$. He mentions two ports of Rhodian colonies: Gelos (Cressa (Oplothiki) and Thysannous. Between these lay Larumna and Pandion Hill stretching into the sea. Then comes the bays: "Thymnias, Schoenus and Bubassius". As he notes, the Aphrodisium Cape belongs to Thymnias Bay, Schoenus is associated with the Hyla settlement and Bybassos relates to Cyrnos. It was perhaps the Aphrodisium Cape which separated Sinus Thymnias and Sinus Schoenus ${ }^{64}$ since different forms of script are elusive for interpretation. Foss \& Reger fix Roman Sinus Schoenus to Deliktaş Bükü ${ }^{65}$. Equally telling is an anecdote transmitted by Burgett et al. ${ }^{66}$. However, the bay is occasionally acknowledged as Hyda or Hylas, in the southeastern part of Losta

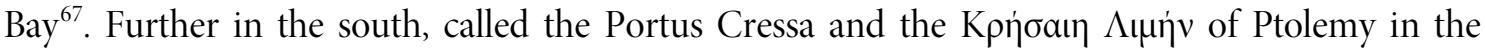
Classical world, the unfortified Serçe Bay acted as the harbour of Casarae, and may even have served Phoinix during the Rhodian protectorate ${ }^{68}$. Foss \& Reger deem Cressa- Serçe Bay a Roman inlet Foss \& Reger ${ }^{69}$ (Map 2).

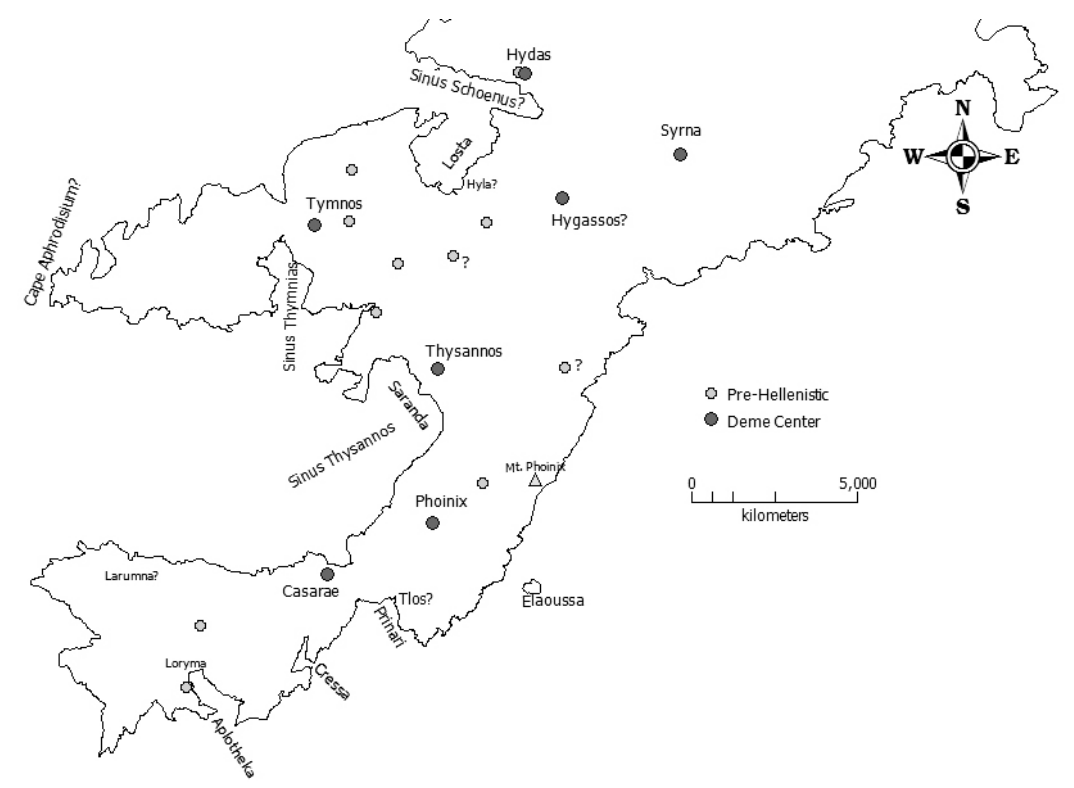

Map 2. Deme Centers in the Peraea

For Bean, Hyda/Hyla is identifiable as Sinus Schoenus/Reedy Bay, which is modern Selimiye. Sinus Schoenus covering Hyda might be modern Orhaniye, too ${ }^{70}$. Küçükeren calls Selimiye Uda, namely Hyla $/ \mathrm{Hyda}^{71}$. With a slight difference in the reading, Peschlow-Bindokat marks it as Hydas ${ }^{72}$. No matter whether Sinus Schoenus indicates a reedy place, no such area is known hereabouts.

63 Mela I. 16.

64 Plin. nat. VI. 29.

65 Foss - Reger 2000, 946, G4. The authors use Hydas interchangeably with Hylas (ibid. 941).

66 Burgett et al. 1984, II. 1010.

67 Sevin 2001, 128.

68 Carter 2004, 13.

69 Foss - Reger 2000, 943, G4.

70 Fraser - Bean 1954, 63; Bean 1971, 162; 2000, 168.

71 Küçükeren 2007, 123.

72 Peschlow-Bindokat 2003, 11. 
Completely referring to the location of inscriptions, Bresson assumes that Selimiye is to be included within the borders of Tymnos ${ }^{73}$. Benter almost puts an end to this equivocality as he describes the the core of the deme of Hydas at an elevation of $270 \mathrm{~m}$ above the sea level embraced with an agricultural hinterland stretching across a valley to the northwest of Turgut Village ${ }^{74}$.

Ancient literature proves very little about some others, if all demes. Yet, Hygassos (Ygassos) has

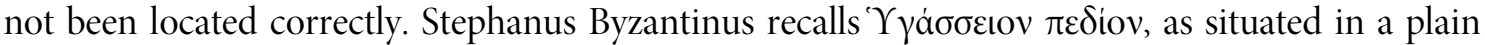

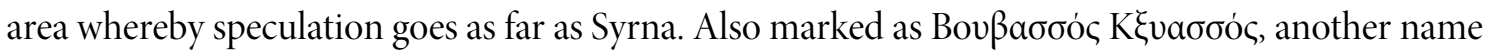

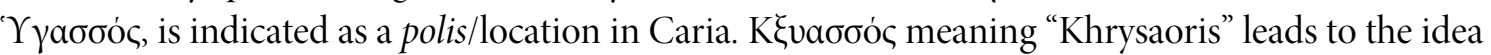
that Hygassos could be a location which was conspicuous enough to be nominated as a rural type settlement, perhaps bigger than that $(s . v \text {. } \Upsilon \text { Y } \gamma \alpha \sigma \sigma o \dot{s})^{75}$. On the one hand, there is a piece of information (acquired through the inscriptions found at the Sanctuary of Hemithea in Kastabos near Hisarönü) commemorating the Hygassians. Accordingly, the Hygassians were registered among the list of donors to the mentioned temple ${ }^{76}$. Foss \& Reger consider that it was a Hellenistic settlement on Losta Bay ${ }^{77}$. Bean makes a mark on its association with modern Selimiye Bay addressing Sinus Schoenus ${ }^{78}$. To Cook, it could be nearby Bybassos in the vicinity of Pazarlık Plain, which is related to the Sanctuary of Hemithea. An epitaph of two Hygassians found in Syrna and another evidenced at Rhodes still remain as two enigma for a precise appointment to any location ${ }^{79}$. Küçükeren assumes that it might be near Orhaniye and Turgut villages ${ }^{80}$. Interestingly, Hygassos is located to the south of Turgut by Peschlow-Bindokat ${ }^{81}$. Not that far, Benter calls attention to Köklüdağ, which exhibits settlement remains up on $450 \mathrm{~m}$ elevation, in the vicinity of Turgut. Regarded as a deme by Umar, it is left to the south of Hisarönü, near Turgut, right on a temenos wall on Bozburun road. The inscription found in Kastabos (noted above) presumably biased the author towards these environs. Perhaps bordered with the temenos wall, the original name of the deme could have been inherited from "Ygeia/Hygeia"- attested as the goddess of health. Already known from the Peraea, the goddess attributable to the cult of Asclepius has links with Syrna. Although the discussion is rather distractive, Benter deems that the fortified island on the opposite side of Orhaniye might be associated with Hygassos ${ }^{82}$. Such confusions in ancient names mask the generic problem of identification.

An acropolis high above Kızılköy, called Asarcık is a valuable site about which limited information is provided by scholars ${ }^{83}$. All around the site situated along a valley descending to the east, regularly dressed walls and large building blocks (which many scholars regard as tombstones)

73 Bresson 1991, 94-101.

74 Benter 1999, 307, 310; 2001, 177-179; 2010, 659-661. Occupation between Geometric and Early Archaic periods was evidenced with fibulas, comparable to those at Ialysos (ibid. 311).

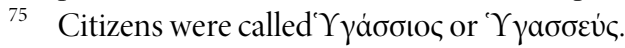

76 Bean 1966 58-65; Bresson 1991, no. 37-38.

77 Foss - Reger 2000, 941, G4.

78 Bean 2000, 168.

79 Cook 1961, 64. The epitaph found in Rhodes appeared with the name'Epıvaí sho was married to a man from Hygassos (ibid.); Cook - Plommer 1966, 159-161.

80 Küçükeren 2007, 15.

81 Peschlow - Bindokat 2003, 11.

82 Benter 2010, 663; Umar 1999, 187, 195-196.

83 Fraser - Bean 1954, 43; Bresson 1991, no. 65; Diler 1994, 442-443. 
are visible. A settlement markedly reflecting Hellenistic fashion was there along the slopes of Asarcik, possibly during the early Roman period. However, it has never been thought this site could have belonged to a core settlement, perhaps a deme center, justifiably, due to a lack of satisfactory data concerning provenance or an ethnic identity except for a dedication made to the cult of Aphrodite at the front terrace of a public building, a possible sanctuary. Regardless of this fragmentary material (a votive plaque) addressing the Roman epoch ${ }^{84}$, we conceive that it could be Hygassos? stretching to the coastal land as far as Losta or relate to any part thereof.

Situated on the east of the Peninsula, Syrna was identified from the Hellenistic and Roman inscriptions ${ }^{85}$. A problem with Syrna occurs with the status of the ancient settlement in the readings of Bean when he states that it was not a Rhodian deme however, it was attractive enough with its Asclepion as evidenced through an inscription ${ }^{86}$. TAY pinpoints it as a Roman settlement ${ }^{87}$. An inscription found on the way to modern Çiftlik Bay implied a ktoina, recalling the Syrnioi. The reason why Bresson ${ }^{88}$ questions the situation of Syrna as a ktoina is explainable with the hints found on a stele (101/300 B.C.) in Bayır Village, belonging to a Hygassian couple. Although nothing was thoroughly addressed, it is debatable whether the ktoina related to the Hygassian territory (90-92). The situation becomes complicated as to whether "ktoina" was employed in lieu of a subdivision of a deme or for any other territorial unit attached to the either three poleis.

Efforts on the identification of demes also need to utilise from the recent discussions, e.g. from amphora finds ${ }^{89}$ and social indicators. Unfortunately, ceramic evidence reported up to now barely throws light on ethnic origins; they are quite informative about the patterns of production represented by the typical Peraean amphora or Rhodian type manufactures revealing a wellestablished stamp system, as also through eponyms. No matter, some scholars often base their arguments on the genealogical traces leaning on a rich epigraphic inventory. A dedication (end of the III ${ }^{\text {rd }}$ century B.C.) made by the Amians to a hegemon of the Peraea at Hisartepe is one good example which backed up their ethnic background ${ }^{90}$. Likewise, an assessment on the original names is made by Meyer when he visualizes the Peraea according to the ethnic divisions. He locates Tymnos to modern Selimiye (ancient Losta), stretching toward modern Turgut and encompassing the environs of Kizılköy under the specific name of "Tymnioi". Understandable from his writing, Tymnos was situated in the north of Thysannous, at the inner angle of Losta Bay while Thysannous lay in the inner angle of the Saranda Beach, at the opposite side of Syme ${ }^{91}$. A perplexity is that

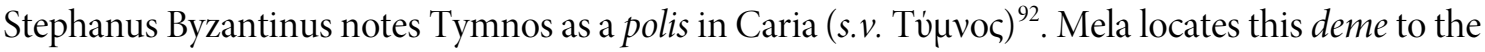
vicinity of Selimiye acknowledged with Thymnos Sinus, ${ }^{93}$ while Pliny possibly associates the same

84 I. Peraia 292; Bresson 1991, no. 65. The inscription is dated to the Roman era due to lettering, however the style of architecture in the immediate surroundings suggests the Hellenistic era (Bresson 1991, 94).

85 Cook 1959, 28, 52; Foss - Reger 2000, 947, G4.

86 Bean 2000, 166-167. Attached to Casarae, Loryma was not a Rhodian deme, either (ibid.).

87 TAY 2007, vol. 7.

88 Bresson 1991, no. 61.

89 Constantakopoulou 2007, 244

90 Bresson 1991, 83, no. 52.

91 Meyer 1925, 50-51.

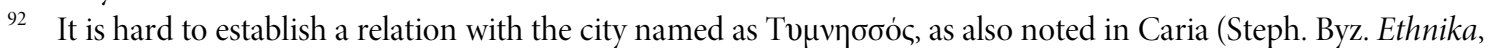
Túuvos).

93 Mela I. 16. 
with Bozburun Bay ${ }^{94}$. Conversely, Tymnos is almost located to Thysannous in the Codex Kultur Atlas $^{95}$. Bean considers that the deme of Tymnos was central modern Bozburun where almost nothing has remained except some inscriptions ${ }^{96}$. Some acknowledge it as "Tymnus" to the northeast of Bozburun" ${ }^{97}$. In the "Atlas of the Greek and Roman World in Antiquity" in the identical location. Tymnos is described as ancient Bosporanos ${ }^{99}$ by Aydaş and that it is 11 nautical miles from Rhodes ${ }^{100}$. TAY identifies it as demos due to previously reported inscriptions about Tymnians ${ }^{101}$. It could be $3 \mathrm{~km}$ north, near Selimiye. However, due to some more inscriptions (found in Selimiye) mentioning the koinon of Tymnians, Fraser \& Bean prefer to include Selimiye within the territorium of Tymnos, which implies that the borders of Tymnos could have extended as far as Selimiye. If Selimiye was the site of Hyla or Hyda, which was never mentioned as a Rhodian deme ${ }^{102}$, it would not be wrong to associate the ancient people of Selimiye with the Tymnians. But it is still hard to make a claim on that as a site named Gemecitdüzü neighboring the Avlana Village near Bozburun (on its east/northeast) but barely detachable from the sites described for the previously discovered epigraphic finds, is full of new questions regarding the probable early traces of settlement in the surroundings of central Selimiye.

For Küçükeren, Larymna was Bozburun, Tymnos was somewhere in the vicinity ${ }^{103}$. The picture becomes unclear as Pliny spells Larumna and Loryma separately ${ }^{104}$. If Larymna was Bozburun, then it must be the problematic side of Tymnos. A discussion on the toponomy has been brought by Umar such that the original Larymna could have been Lar(a)umna, as Fraser \& Bean once suggested it to be Larumna. It stood on top of a moderate hill (Asartepe) in the northeast of Bozburun, with a necropolis facing the bay on the southwest slope. The location so described by the author is known locally as Kaletepe. Having parallels, Peschlow-Bindokat assume that Tymnos was exactly where Kaletepe stands in Bozburun, while Larymna has connection to the north of Loryma at the tip of the Peninsula, now known as Aziziye ${ }^{105}$. Interestingly, almost none of the scholars (apart from the few cases mentioned above) have left a mark on Kaletepe up to now. It is also a place which deserves attention, with potsherds suggesting a wider time span including the Classical era. The site has a catchment area stretching to Avlana Village which is in connection with the Yeşilova Quarter of modern Bozburun and the agricultural enclaves known locally as Örteren in the west.

We see that Thymnos Sinus could be Sinus Losta in ATL. With such contradictory information to hand, it seems difficult to say that Larymna was the deme center of Tymnos- named due to

94 Plin. nat. V. 29.

95 Codex Kultur Atlas 1965.

96 Bean 1971, 162.

97 Bayrak 1994, 496.

98 Hammond 1981.

99 Chaviaras - Chaviaras 1911, 64-65; Fraser 1983, 137-139.

100 Aydaş 2010, 4-5. The author names Selimiye as Tymnos (ibid.11).

101 TAY 2007, vol. 7.

102 Fraser - Bean 1954, 62.

103 Küçükeren 2007 119, 123. Küçükeren suggests that the meaning of Larumna comes from the people of sand in the Luwian language (ibid. 201).

104 Plin. nat. V. 29.

105 Fraser - Bean 1954, 59; Umar 1999, 216; Peschlow-Bindokat 2003, 11. 
Bozburun Bay. It could well be somewhere between Gelos (if Serçe Bay) and Thysannous ${ }^{106}$ or any other. Meanwhile, the name, Bosporanoi, was discovered on an Imperial period tomb inscription found near Bozburun. The reading was previously made by Chaviaras \& Chaviaras taking the words

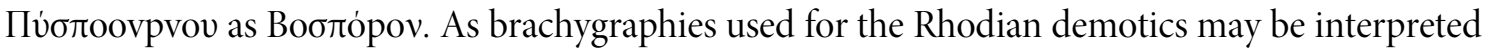
differently, it could be conflictive to claim Bosporonai as Bozburun, as the deme center of Tymnioi ${ }^{107}$. Also, the ancient name derived from abbreviations as "Bosporus" is an open question as to where the strait stood ${ }^{108}$. Turning back to the most controversial, two places called Larymna and Paridon by Pliny ${ }^{109}$ makes the situation difficult to interpret, however, there is no hindrance, although it may sound absurd, to why we should not contemplate the idea that Cape Aphrodisias(um) (previously noted) could be modern Cape Ata(b)ol in the western tip of modern Bozburun as these names evoke each other apart from the nuances.

Fraser \& Bean make a solid mark that on the east of Bozburun Bay, in modern Sögüt, there lies Thysannous ${ }^{110}$. Hearing from Pechlow-Bindokat, Thysannous is in Söğüt, Phoinix is located to the north of Taşlıca where the lower village (Fenaket) was probably disregarded by the scholar. Instead of Phoinix, the author prefers to call it Tlos/Gelos, which falls to the northeast of Casarae on the coastal band ${ }^{111}$. Bean is not free from doubt about the deme center of Thysannous as he bases his argument on poor visible evidence. Anyway, he speculates that, traceable with the polygonal wall remains, Thysannous was up in Saranda Village ${ }^{112}$. Debord \& Varinlioğlu show Thysannous as "Thyssanonte" exactly to the east of Bozburun and Phoinix to the southeast of Thyssanonte ${ }^{113}$. All is full of new questions. But what Bean attests is persuasive since the Acropolis (Oyuktepe) having debris scattered high above Saranda Bay (the modern Cumhuriyet Quarter) and the lower settlement on the coastal area remain clearly visible today ${ }^{114}$.

In the thick volume of the inventory of Archaic and Classical poleis, Hansen \& Nielsen provide a full version of the updated pre-Hellenistic settlements, none of which are characterized as a polis in the Peraea ${ }^{115}$. Probably having origins dating from the $\mathrm{V}^{\text {th }}$ century B.C., Phoinix is recognizable with a fortress (located in Fenaket) with different masonry types. The earliest inscriptions from the III $^{\text {rd }}$ century B.C mention a damos, a naos of Dionysos, a prytaneus, as well as the priests of Athena and Zeus Polieus ${ }^{116}$. Based on onomastic scrutiny, numerous funerary inscriptions found in Fenaket are now datable to the $\mathrm{IV}^{\text {th }}$ - II ${ }^{\text {nd }}$ centuries B.C. ${ }^{117}$. On the map visualized by Başgelen, Phoinix and

106 Fraser - Bean 1954, 60-61.

107 Chaviaras - Chaviaras 1911, 64-65; Fraser 1983, 137-139.

108 Fraser - Bean 1954, 60-61.

109 Plin. nat. V. 29.

110 Fraser - Bean 1954, 59.

111 Pechlow-Bindokat 2003, 11.

112 Bean 2000, 168.

113 Debord - Varinlioğlu 2001, 87.

114 Bean 2000, 168.

115 Hansen - Nielsen 2004.

116 Flensted - Jensen 2004, 1109-1110. For damos and construction of the naos of Dionysus, see: I. Peraia, 101; Bresson 1991, 149 (I. 1). For the priest of Athena and Zeus Polieus, see: I.Peraia, no. 103; Bresson 1991, no. 148 (II. 5-6). For prytaneus (prytanis), see: I.Peraia, no.'s 138; 153. For more on Athena Lindia and Zeus Polieus, refer to Haussoullier, B. (1880). Inscription d'Halicarnasse. Bulletin de Correspondance Hellénique 4: 522-524.

117 Bresson 1991, 134-153. 
Elaeoussa Island are situated in the vicinity of the isthmus ${ }^{118}$. Dürrbach \& Radet pinpoint Phoinix as one of the main settlements in the Rhodian Peraea ${ }^{119}$. Fraser \& Bean associate it with Barayüksek Dağ (Karayüksek Dağ, $536 \mathrm{~m}$ ). Although no demotic of Phoinix has been witnessed up to now, the inscriptions have disclosed that it was a deme with a fortified Acropolis on top of a hill between the Lower and Upper Fenaket. The Acropolis could have been the center of Prinari Bay (Pınarlıbükü/ Pinarbükü, modern Gedik Bay or ancient Tlos (possibly Gelos) ${ }^{120}$, which was a Hellenistic and Roman site. Foss \& Reger associate Tlos with Tracheia Mountain (Koresos) but no consensus has been reached on the precise name ${ }^{121}$. On the other hand, we are already informed of the ethnic name of Tloans attributable to the region of Phoinix ${ }^{122}$. Aydaş addresses an inscription (I ${ }^{\text {st }}$ century B.C.) which was found in Lagina, mentioning Tlos as the demos of Kamiros ${ }^{123}$. Yet we need to remain skeptical as the pronunciation of the names might be deceptive, e.g. the two Lycian cities were "Pinara and Tlos" while we also have the names of "Prinari and Gelos" in Caria. If there was a locality called Tlos, Tloioi could have implied the sub-ethnic in a territorium whose center was Phoinix or the deme could have been based on the mentioned ethnic in that it could have been named thereafter.

The Acropolis of Phoinix was obviously Hisartepe standing in the former Fenaket Village, however another site known locally as Kaledağ to the east of the modern Taşlica Village (northeast of the Acropolis) deserves special attention with its untouched ramparts. This site was possibly the robust fortress associated with the Phoinix Mountain by Strabo ${ }^{124}$.

Casarae has been safely located to Asardibi, from the inscriptions found in-situ at Bozuk Village $^{125}$. Documented through the tombstones reported from Rhodes and Asardibi, the deme is depicted as a "Classical site" situated on the northern bay over the isthmus in the Peraea ${ }^{126}$. Hicks conveys a further note that it lies 3 miles northeast of Loryma, the Bay of Aplotheka (most probably Oplothiki) ${ }^{127}$. The site was essentially dated from pottery finds in Asardibi and underwater data from the northern harbour of Serçe Bay ${ }^{128}$. Much work has been conducted with respect to Loryma, which falls into the borders of the deme of Casarae. Held clarifies its exact location near the promontory acknowledged as Karaburun. Regarding the political status, it lost the polis character after the Classical era ${ }^{129}$. That is to say, the position of this small harbour settlement leaves no doubt when it is compared to many other sites in the Peraea. In Casarae, there is another site, now a dried up lake which is known locally as Kiran where the ruins (mainly recognizable from an altar and theatre-like edifice) suggesting the Archaic and Classical era which were surveyed by Kuban \&

118 Başgelen 2005, 20-21.

119 Dürrbach - Radet 1886, 245. The definition of the site as Phenikeh (not situated on the coastline), goes as: " $a$ egale distance des deux rivages de la peninsule, au fond d'un sorte de cirque tres encaisse" (ibid. 246).

120 Fraser - Bean 1954, 58.

121 Foss - Reger 2000, 947, G4.

122 IG XII, 1 1449; Robert 1983, 257; Bresson 1991, 148, 150, 154.

123 Aydaş 2010, 87-88

124 Strabo XIV. 2.

125 Fraser - Bean 1954, 59; Foss - Reger 2000, 942, G4.

126 Flensted- Jensen 2004, 1109-1110.

127 Hicks 1889, 46-47.

128 http://nauticalarch.org

129 Held 2005, 96; TAY 2007, vol. 7. 
Saner. The site neighbors Loryma in the northern sector of Casarae. Not that distant, the authors inform us of another site called Kumalanı, which is still undated but noticeable with circular steles. Here is a plain settlement suitable for agriculture and easily watched by a hill (local Asar Dağ), namely Hisardağ $1^{130}$. There must have been a connection between Kiran and Hisardağ ${ }^{131}$. We postulate that Larumna might be modern Kumalanı (also basing the discussion on etymology, see note 103) which is situated half way between Loryma and Hisardağ, in which case Pliny might be right when he makes a straight discrimination between the two neighbouring sites of Loryma and Larumna.

When referred to the Digital Atlas of Roman and Medieval Civilizations, the positioning of the demes and some modern names are seen to be roughly given upon a blank sheet. Also, Casarae (Kasara) and Tlos (Phoinix) stand too close together so nothing is comprehendible for the latter. Despite the fact that, the epigraphical evidence, as elaborated through the hints about social and religious life ${ }^{132}$, help the reader to comment on some more realistic locations to some extent, the safest way to arrive at a consensus would be through referring to the survey results carried out until recently, in specific parts of the Peninsula. Hence, data relevant to a few locations are available in the reports of Held, Benter and Kuban \& Saner ${ }^{133}$. In the meantime, a contribution to the previous works was undertaken through the extensive surveys (practically limited to only five demes which are hypothetical Hygassos? associated with Losta; Syrna; Tymnos; Thysannous and Phoinix) conducted in 2009-2012, with a view to present additional data and to question the problem of period (subject to replenishment). A wide category of finds from the architectural remains to the

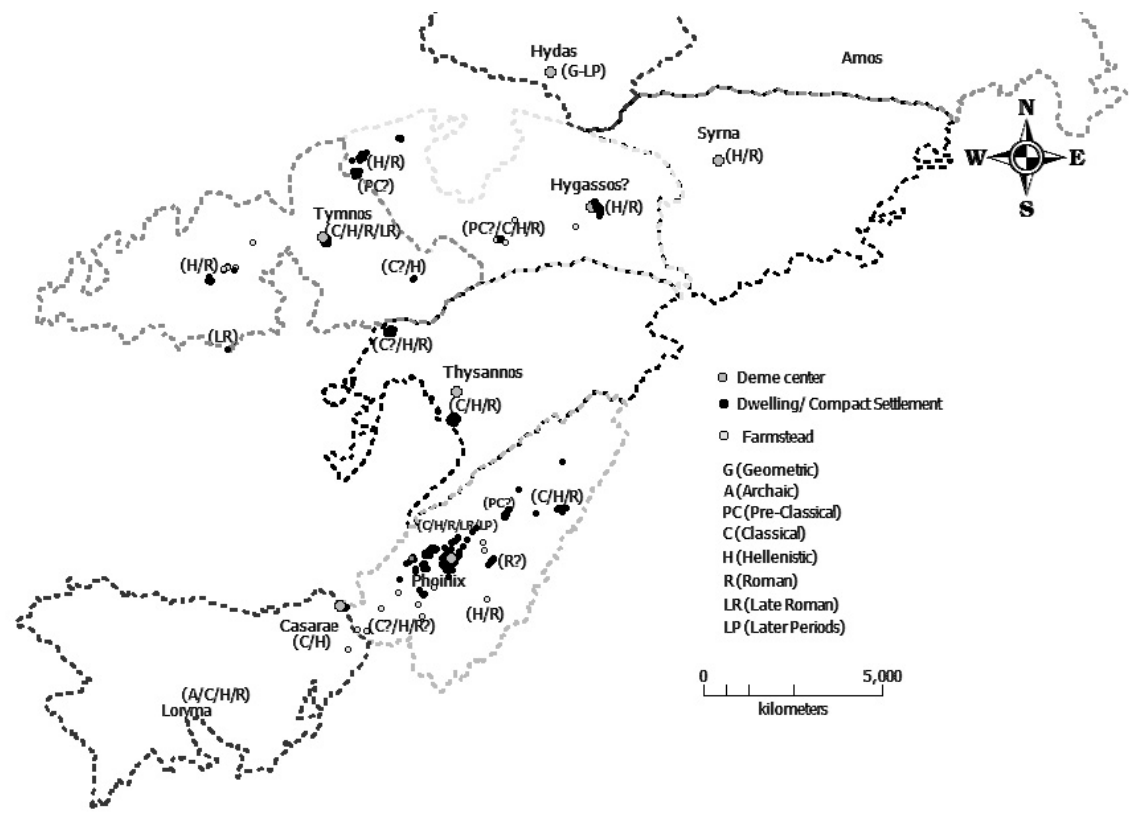

Map 3. Territorial Designation in the Peraea

130 The authors use "Asar Dağ" instead of the official name-Hisardağ 1 in this part of Casarae. They must be mentioning this same location.

131 Kuban - Saner 1999, 287-289; Kuban - Saner 2005, 401.

132 Fraser - Bean 1954, 122.

133 Held 1996, 1999-2003, 2005-2006; Kuban - Saner 1999, 2000, 2005; Benter 1999, 2001, 2010. 
typical masonry, ramparts, pyrgoi, hydro-works, ancient routes, farmsteads, pressing installations, burial remains and potsherds formed the set of criteria to reconstruct/reassess the possible territoriums of demes and trace them in view of the settlement context. To conclude, reading from (the map compiled by) Foss \& Reger ${ }^{134}$, referring to the survey results of the scholars noted above and incorporating the new data uncovered during the 2009 to 2012 campaigns, we can display the approximate and/or associated periods (Map 3), although we take account of a future revision under the recent silhouette. Obviously, epistemological problems, as well as ambiguities emanating from the epigraphical interpretations have left the mainland with a subtlety which has posed growing difficulties in designating spatial limits. Hence, a reassessment on the deme locations and estimation considering the physical and social boundaries (thus their scope of influence limited to the study area) about which scholars have not reached a clear agreement is also made and visualized through Table 2 and Map 3, respectively. The method of territorial designation and details of contextual data are not the concern of this paper, since it is deemed a different topic of discussion which has been undertaken. Map 3 also shows what is considered to be the approximate position of the peninsula, unless each deme interrupted another or aspired for the other, in part or in full. Based upon the presumptive territoriums and further study with sampling, it appears that the deme centers (often the Acropoleis) would not exceed 2-4 ha in essence but the natural restrictions define the possible limits for the territorium of each deme. A topical reference is also owed to the recent surveyors in that the values put forward (e.g., Benter $(1999,308)$ limit the size of the Acropolis of Hydas as 3.5 ha, enclosed by walls) by them have also been taken into account in the assignment of the range for the size of the centers of deme.

On the other side, there is one point that we chose not to skip: new traces of early settlement. These were observed in the vicinity of demes (particularly Losta/Hygassos?, Thysannous and Phoinix), which indicate the probable terminus post quem for the Carian occupation. Although it is contentious for the present, we can say, the secure positions of such enclaves on top of defensive hills having quite good visibility may address the original locations of the demes, forming some of the earliest komai (Map 2). The point is, we can barely bring up toponomical discussions in relation to the pre-Hellenistic habitations but can suggest all of them must have acted as the indigenous constituents of the Carian Chersonesos.

\begin{tabular}{|l|l|}
\hline Deme Name & Location \\
\hline Hydas & Turgut \\
\hline Syrna & Bayır \\
\hline Losta/ Hygassos? & Selimiye- Kızılköy \\
\hline Tymnos & Bozburun \\
\hline Thysannous & Söğüt \\
\hline Phoinix & Taşlıca \\
\hline Casarae & Bozuk \\
\hline
\end{tabular}

Table 2. Demes of the Peraea

134 Foss - Reger 2000, G4. 


\section{Discussion}

Evidently, colleagues have not reached unanimous agreement on the exact names and locations of the Peraean demes and/or sites, from the literary evidence. The recent picture, albeit with the destructive processes over the last few decades and the ambiguities in the scripts of the scholarly world over the last two centuries, show the modern settlements associated with the Hellenized demes are Turgut (Hydas), Kızılköy (hypothetical Hygassos complemented with Losta Bay), Bayır (Syrna), Bozburun (Tymnos), Söğüt (Thysannous), Taşlıca (Phoinix) and Bozuk (Casarae). It seems that the designation of the territorial boundaries of the demes was previously achieved as a result of the egalitarian atmosphere of the Classical period and continued thereafter. Regarding the general literature and field campaigns carried out in 2009-2012, the deme centers/Acropoleis of the mentioned demes are attributable to Kaletepe $(270 \mathrm{~m})$, Yancağız Tepe $(200 \mathrm{~m})$, Asarcık (410 m), Kaletepe (205 m), Oyuk Tepe (199 m), Hisartepe (222 m), Hisardibi (35 m)/the environs of Hisardağ $(415 \mathrm{~m})$ ?, respectively.

Despite the weaknesses in the ancient literature ${ }^{135}$ and discreteness in epigraphical evidence, the demes located in the west of the Peraea seem to have been attached to the mother polis of Kamiros, those lying in the east to Lindos, whereas the case is harder to tackle for Ialysos. More reasonably, the determinant factor must have been the position of natural harbors and auxiliary edifices leading the way to the most suitable corridors. For instance, Casarae apparently masters the east and the western tips of the Peninsula but her dependency on Lindos could have arisen from the advantageous positions of Loryma and Serçe Bay facing the east. A refreshed category for the known demes is that Tymnos and Phonix were the Kamiran demes; Physcus, Amos and Casarae were Lindian whilst the rest are still open to debate. If there were a total of 13 demes for the three old poleis on the mainland (except for the others yet undefined), this makes more than four demes allocable to each polis, providing that a complete egalitarian atmosphere prevailed in Rhodes during the Hellenistic "colonization". But as the number of six demes was previously restored to Kamiros, we can propose that it is the cogent number. To date the relation of the Peraean demes to the three old poleis, or even discussions on their numbers have been questioned regarding some certain criteria, e.g. the distance effect as emphasized, defensibility, epigraphic evidence, etc. However, attempts at designating the demes to a mother polis according to their physical position on the Peninsula and endeavors to determine the number of the Peraean demes through counting the number of Peraean fortifications remain immature, until the list of demes is updated with the help of a complete record of epigraphical material at some point in the future. A similar approach prevails for this paper, as the territorial designation in view of the natural boundaries (but also based on egalitarianism) and the loci of archaeological finds (without the dismissal of previously reported sites), and the deme centers will need to be further investigated and cross-examined. Unless evidence supported contra-arguments are brought for the presently unknown deme of Hygassos, we may have to be content with renaming a long-neglected Acropolis (in the environs of Kizllköy) which has never been included to date in the list of scholars. No groundbreaking result is attempted. If not safe for the moment, we might well take it for granted that the "Hellenistic-Roman Hygassos" might have had a deme memory dating from the Classical era.

135 But basically referring to the views of Meyer 1925; Fraser - Bean 1954; Bean - Cook 1957; Calder - Bean 1958; Jones 1987; Dmitriev 1999; Papachristodoulou 1999. 


\section{Acknowledgements}

The surveys were launched for the fulfillment of the Ph.D. dissertation entitled, "The Rural Settlement Pattern of the Bozburun Peninsula During Classical and Hellenistic Periods", under the auspices of the Ministry of Tourism and Culture of the Republic of Turkey. We would like to express our gratitude and sincere thanks to Prof. Dr. Numan TUNA for his guidance and support throughout the entire work. We offer many thanks to the General Directorate of Cultural Assets and Museums of the Ministry of Culture and Tourism, for having granted the formal permits and the Directorate of Marmaris Museum for the support given to the completion of these studies which, we hope, can be continued in the future. 


\section{BIBLIOGRAPHY}

\section{Ancient Sources}

Plin. nat.

Plut. Lys.

Polyb.

Mela

Strab.

Steph. Byz. Ethnika

\section{Modern Sources}

Aydaş 2010

Başgelen 2005

Bayrak 1994

Bean 1966

Bean 1971

Bean 2000

Bean - Cook 1957

Benter 1999

Benter 2001

Benter 2010

Berthold 1984
(= G. Plinius Secundus "Maior", Naturalis Historia)

Natural History (Vols. I-X; Books 1-37). Trans. by Rackham, H., Jones, W.H.S. and Eichholz, D. E. London: Harvard University Press. (19491954).

(= Plutarch, Lysander)

Plutarch. Lives (Vol. 4): Alcibiades and Coriolanus Lysander and Sula. Trans. by Perrin, B. London: Harvard University Press. 1916.

(= Polybios, Historiai)

Polybius. The Histories (Vol. 6, Books 28-39). Trans. by Paton, W. R. London: Harvard University Press. (1927).

(= Pomponius Mela, De Chorographia)

Chorographie (Livres 1-3). Trans. by Silberman, A. Paris: Les Belles Lettres. (2003).

(=Strabo, Geographika)

Strabon. Geographika: Antik Anadolu Coğrafyası (Books 12-14). Trans. by Pekman, A. İstanbul: Arkeoloji ve Sanat Yayınları. (2005).

(= Stephanos Byzantinos, Ethnika)

Stephan von Byzanz (Stephanus Byzantinus). Ethnika (Stephani Byzantii Ethnicorum Quae Supersunt Ex Recensione Augusti Meineke). Graz: Akademische Druck- U. Verlagsanstalt (Unverändenter Abdruck der 1849 in Verlag G. Reimer in Berlin erschienenen Ausgabe). (1958).

M. Aydaş, M.Ö 7. Yüzyllan 1. Yüzylla Kadar Karya ile Rodos Devleti Arasındaki İlișkiler. İstanbul 2010.

N. Başgelen, Eski Haritalarda Batı Anadolu (Western Anatolia in Ancient Maps). İstanbul 2005.

M. O. Bayrak, Türkiye Tarihi Yerler Kılavuzu. İstanbul 1994.

G. E. Bean, "The Inscriptions". Eds. J. M. Cook - W. H. Plommer, The Sanctuary of Hemithea at Kastabos. Cambridge (1966) 58-65.

G. E. Bean, Turkey Beyond the Meander: An Archaeological Guide. London 1971.

E. Bean, Eskiçağda Menderes'in Ötesi (Turkey Beyond the Meander). Çev.: P. Kurtoğlu, İstanbul 2000.

G. E. Bean - J. M. Cook, "The Carian Coast III". The Annual of the British School at Athens 52 (1957) 58-147.

M. Benter, "Hydas Yüzey Araştırması 1998”. Araştırma Sonuçları Toplantısı 17 (2) (1999) 307-321. 24-28. Mayıs 1999, Ankara.

M. Benter, "II. Hydas Yüzey Araştırması 2000". Araştırma Sonuçları Toplantısı 19 (1) (2001)177-188. 28. Mayıs-01 Haziran 2001, Ankara.

M. Benter, "Hydas: Bozburun Yarımadası'nda Müstahkem Bir Yerleşim Yeri”. Belleten 74/271 (2010) 659-672.

R. M. Berthold, Rhodes in the Hellenistic Age. Ithaca - London 1984. 
Bresson 1991

Burgett et al. 1984

Calder - Bean 1958

Carter 2004

Chaviaras - Chaviaras 1911

CKA

Constantakopoulou 2007

Cook 1959-1960

Cook 1961

Cook 1962

Cook - Plommer 1966

Crielaard 2009

Debord - Varinlioğlu 2001

Diler 1994

Diler 2007

Dmitriev 1999

Dürrbach - Radet 1886

Flensted - Jensen 2004

Foss - Reger 2000

Fraser 1983

Fraser - Bean 1954

Gabrielsen 2000
A. Bresson, Recueil des Inscriptions de la Pérée Rhodiene (Pérée Intégrée). Paris 1991.

C. Burgett, M. Rockmore - G. Quinting, Gazetteer of Turkey (vols 1-2). Washington D.C 1984.

W. M. Calder - G. E. Bean, A Classical Map of Asia Minor. Supplementary to Anatolian Studies 7, 1958.

R. S. Carter, "The Region of Serçe Limanı in Classical Times". Eds. G. F. Bass, S. D. Matthews - J. R. Steff et al., Serçe Limani: An EleventhCentury Shipwreck; The Ship and Its Anchorage, Crew, and Passengers (vol. 1). Texas (2004) 13-21.

M. Chaviaras - N. Chaviaras, "Archaiologike Ephemeris". 58 (1911) 6465 .

Codex Kultur Atlas.1965.

C. Constantakopoulou, The Dance of the Islands: Insularity, Networks, The Athenian Empire, and the Aegean World. Oxford 2007.

J. M. Cook, "Greek Archaeology in Western Asia Minor". Archaeological Reports 6 (1959-1960) 27-57.

J. M. Cook, "Cnidian Peraea and Spartan Coins". The Journal of Hellenic Studies 81 (1961) 56-72.

J. M. Cook, The Greeks in Ionia and the East. London 1962.

J. M. Cook - W. H. Plommer, The Sanctuary of Hemithea at Kastabos. London 1966.

J. P. Crielaard, "Cities". Eds. K. A. Raaflaub - H. van Wees, A Companion to Archaic Greece, United Kingdom (2009) 349-372.

P. Debord - E. Varinlioğlu, Les Hautes Terres de Carie. Bordeaux 2001.

A. Diler, "Akdeniz Bölgesi Antik Çağ Zeytin ve Üzüm Presleri, 1993". Araştırma Sonuçları Toplantısı 12 (30 Mayıs-03 Haziran 1994) 441-459.

A. Diler, (2007). Kedrai (Sedir Island). SMAP III EU Gökova Project. İstanbul 2007.

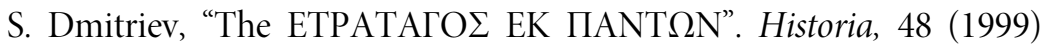
243-253.

F. Dürrbach - G. A. Radet, "Inscriptions de la Péréé Rhodienne". Bulletin de Correspondance Hellénique 10 (1886) 245-269.

P. Flensted - P. Jensen, "Karia". Eds. M. H. Hansen - T. H. Nielsen, An Inventory of Archaic and Classical Poleis: An Investigation Conducted by the Copenhagen Polis Center for the Danish National Research Foundation. Oxford (2004) 1108-1137.

C. Foss - G. Reger, "Map 61 Ephesus Introduction, 1994 (vol. 2, part 4 : Graecia- Asia Minor)”. Ed. R. J. A. Talbert, Barrington Atlas of the Greek and Roman World. Princeton (2000) 937-957.

P. M. Fraser, "The Bosporanoi of the Rhodian Peraea". The Journal of Hellenic Studies 103 (1983) 137-139.

P. M. Fraser - G. E. Bean, The Rhodian Peraea and Islands. London 1954. V. Gabrielsen, "The Synoikized Polis of Rhodes". Eds. P. Flensted-Jensen, 
Hammond 1981

Hansen - Nielsen 2004

Held 1996

Held 1999

Held 2000

Held 2001

Held 2002

Held 2003

Held 2005

Held 2006

Hicks 1889

Hornblower 1982

Held 1991

Hornblower - Spawforth 2003

IG

I.Peraia

Jones 1983

Jones 1987

Kiepert 1898
T. H. Nielsen - L. Rubinstein, Polis and Politics: Studies in Ancient Greek History. Aarhus (2000)177-205.

N. G. L. Hammond, Atlas of the Greek and Roman World in Antiquity. New Jersey 1981.

M. H. Hansen - T. H. Nielsen, "Part III: Indices". Eds. M. H. Hansen T. H. Nielsen, An Inventory of Archaic and Classical Poleis: An Investigation Conducted by the Copenhagen Polis Center for the Danish National Research Foundation, London (2004) 1253-1396.

W. Held, "1995 Yılı Loryma Araştırması". Araştırma Sonuçları Toplantısı 14 (1) (27-31 Mayıs 1996) 165-183.

W. Held, "1998 Yılı Loryma Araştırması”. A raştırma Sonuçları Toplantısı 17 (2) (24-28 Mayıs 1999) 295-306.

W. Held, "Forschungen in Loryma 1999 (1999 Yılı Loryma Araştırması)". Araştırma Sonuçları Toplantısı 18 (1) (22-26 Mayıs 2000) 149163.

W. Held, "Forschungen in Loryma 2000 (2000 Yılı Loryma Araştırması)". Araştırma Sonuçları Toplantısı 19 (1) (28 Mayıs-01 Haziran 2001)189-203.

W. Held, "Forschungen in Loryma 2001 (2001 Yılı Loryma Araştırması)". Araştırma Sonuçları Toplantısı 20 (1) (27-31 Mayıs 2002) 289301.

W. Held, "Neue und Redivierte Inschriften aus Loryma und der Karischen Chersones”. Epigraphica Anatolica 36 (2003) 55-86.

W. Held, "Loryma ve Karia Chersonesos'unun Yerleșim Sistemi". Olba 12 (2005) 85-100.

W. Held, "Loryma". Ed. W. Radt, Stadtgrabungen und Stadtforschung im Westlichen Kleinasien Byzas 3, İstanbul (2006) 187-198. Internationales Symposion, 6-7 August 2004, Bergama (Turkei). Deutsches Archäologisches Institut Abteilung.

E. L. Hicks, "Inscriptions from Casarea, Lydae, Patara and Myra". The Journal of Hellenic Studies 10 (1889) 46-85.

S. Hornblower, Mausolus. Oxford 1982.

W. Held, "Greece: The History of the Classical Period". Eds. J. Boardman, J. Griffin - O. Murray, The Oxford History of Greece and the Hellenistic World. Oxford (1991)142-176.

2003.

Inscriptiones Grecae.

IK Rhodische Peraia.

A. H. M. Jones, The Cities of the Eastern Roman Provinces ${ }^{2}$. Second edition revised by M. Avi-Yonah, G. Bean - M. Gough et al., Amsterdam 1983.

N. F. Jones, Public Organization in Ancient Greece: A Documentary Study. Philadelphia 1987.

H. Kiepert, Atlas Antiquus: Zwölf Katren zur Alten Geschichte. Berlin 
Kuban - Saner 1999 Z. Kuban - T. Saner, “Kıran Gölü 1998”. Araştırma Sonuçları Toplantısı 17 (2) (24-28 Mayıs 1999) 287-295.

Kuban - Saner 2000

Kuban - Saner 2005

Küçükeren 2007

Ma 1998

Marchese 1989

Meritt et al. 1939-1949-1950-1953

Z. Kuban - T. Saner, "Kıran Gölü 1999". Araştırma Sonuçları Toplantısı 18 (1) (22-26 Mayıs 2000) 163-169.

Z. Kuban - T. Saner, "Kıran Gölü Kutsal Alanı 2004". Araștırma Sonuçları Toplantısı 23 (2) (30 Mayıs- 03 Haziran 2005) 395-403.

C. C. Küçükeren, Ege'de Bir Anadolu Uygarlığı: Karya (Karuwal Karkal Karkişa/Krk)². İstanbul 2007.

J. Ma, "The Koinon of the Laodikeis in the Rhodian Peraea". Epigraphica Anatolica 28 (1998) 9-10.

R. T. Marchese, The Historical Archaeology of Northern Caria: A Study in Cultural Adaptations. Oxford 1989.

B. D. Meritt, H. T. Wade-Gery - M. F. McGregor, The Athenian Tribute Lists, vols 1-4. Cambridge - Massachusetts - Princeton - New Jersey 1939-1949-1950-1953.

Meyer 1925

E. Meyer, Die Grenzen Der Hellenistischen Staaten in Kleinasien. Zürich 1925.

Osborne 1990

R. Osborne, "The Demos and Its Divisions in Classical Athens". Eds. O. Murray - S. Price, The Greek City from Homer to Alexander. Oxford (1990) 265-294.

Papachristodoulou 1999 I. Papachristodoulou, "The Rhodian Demes Within the Framework of the Function of the Rhodian State". Eds. V. Gabrielsen, P. Bilde - T. Engberg-Pedersen et al., Hellenistic Rhodes: Politics, Culture, and Society, 27-44. Studies in Hellenistic Civilization (vol. 9). Aarhus 1999.

Peschlow - Bindokat 2003

A. Peschlow - Bindokat, Frühe Menschenbilder: Die Prähistorischen Felsmalereien des Latmos-Gebirges (West Türkei). Mainz 2003.

Reger 1999

Reger 2007

G. Reger, "The Relations between Rhodes and Caria from 246 to 167 BC”. Eds. V. Gabrielsen, P. Bilde - T. Engberg-Pedersen et al., Hellenistic Rhodes: Politics, Culture, and Society. 76-97. Studies in Hellenistic Civilization (vol. 9). Aarhus 1999.

G. Reger, "Karia: A Case Study". Eds. H. Elton - G. Reger, Regionalism in Hellenistic and Roman Asia Minor, 89-97. Acts of the Conference, 22-24 August 1997, Hartford, Connecticut. Bordeaux 2007.

Rice 1988

E. E. Rice, "Adoption in Rhodian Society". Eds. S. Dietz - I. Papachristodoulou, Archaeology in the Dodecanese. Copenhagen (1988) 138145.

Rice 1999

E. E. Rice, "Relations Between Rhodes and the Rhodian Peraea". Eds. V. Gabrielsen, P. Bilde - T. Engberg-Pedersen et al., Hellenistic Rhodes: Politics, Culture, and Society, 45-53. Studies in Hellenistic Civilization (vol. 9).

Robert 1983

L. Robert, "Une Épigramme Hellénistique de Lycie". Journal des Savants 4 (1983) 241-258.

Sevin 2001
V. Sevin, Anadolu’nun Tarihi Coğrafyası. Ankara 2001. 
Sherk 1990

Şahin 1976

Torr 1885

Tuna 1999

TAY

Umar 1999

Uyguç 1992

van Bremen 2009

\section{Digital Sources}

DARMC

Searchable Greek Inscriptions

INA
R. K. Sherk, "The Eponymous Officials of Greek Cities: Mainland Greece and the Adjacent Islands". Zeitschrift für Papyrologie und Epigraphik 84 (1990) 231-295

M. Ç. Şahin, The Political and Religious Structure in the Territory of Stratonikeia in Caria. Ankara 1976.

C. Torr, Rhodes in Ancient Times. London 1885.

N. Tuna, "Batı Anadolu'da Geç Klasik Dönem Kentleşme Hareketleri”. Çağlar Boyunca Anadolu'da Yerleșim ve Konut Uluslararası Sempozyumu (International Symposium on Settlement and Housing in Anatolia Through Ages), İstanbul (1999) 477-494. Habitat II, 5-7 Haziran 1996.

Türkiye Arkeolojik Yerleşmeleri Projesi, (2007). Türkiye Arkeolojik Yerleşmeleri 7 (Yunan-Roma/Psidia- Karia). İstanbul: Tarih, Arkeoloji, Sanat ve Kültür Mirasını (TASK) Koruma Vakfı.

B. Umar, Karia: Bir Tarihsel Coğrafya Araștırması ve Gezi Rehberi. İstanbul 1999.

A. Uyguç, Güneybatı Anadolu’nun Tarih Öncesi Halkı: Kar'lar. Çine 1992.

R. van Bremen, "Networks of Rhodians in Karia". Eds. I. Malkin, C. Constantakopoulou - K. Panagopoulou, Greek and Roman Networks in the Mediterranean, London - New York (2009) 109-129.

Digital Atlas of Roman and Medieval Civilizations (DARMC). Available from:

http://www.arts-humanities.net/projects/digital_atlas_roman_medieval_civilization_darmc

A Scholarly Tool in Progress (The Packard Humanities Institute- Project Centers/ Aegean Islands, incl. Crete (IG XI-[XIII]) and Asia Minor: Caria, Rhodian Peraia (I.Peraia. 292) (25.03.2013). Available from: http://epigraphy.packhum.org/inscriptions/main Archived Issues of INA Quarterly (Institute of Nautical Archaeology) Available from:

http://nauticalarch.org 